\title{
Whole-body albumin mass and distribution in rats fed on low-protein diets
}

\author{
By W. A. COWARD and M. B. SAWYER \\ MRC Dunn Nutrition Unit, Dunn Nutritional Laboratory, University of Cambridge \\ and Medical Research Council, Milton Road, Cambridge CB4 IXJ
}

(Received 8 March 1976- Accepted 26 May 1976)

\begin{abstract}
I. From 5 weeks of age, control and experimental rats were given diets containing 2 ro and $3 \mathrm{I} \mathrm{g}$ protein $/ \mathrm{kg}$ respectively, and killed for analysis at $0,2,5,8,12$ and $20 \mathrm{~d}$ after the start of the experiment. At these times estimates were made of plasma albumin concentration, plasma volume and total vascular and extravascular albumin mass.

2. Plasma albumin concentrations were significantly lower in the experimental animals when compared to controls at 8,12 and $20 \mathrm{~d}$ but plasma volumes ( $\mathrm{ml} / \mathrm{kg}$ body-weight) tended to be greater in the former animals. Total vascular albumin mass ( $\mathrm{g} / \mathrm{kg}$ body-weight) was significantly less in experimental animals compared to controls at 8 and $20 \mathrm{~d}$, but was significantly reduced below values at $0 \mathrm{~d}$ only at $20 \mathrm{~d}$.

3. Extravascular albumin mass ( $\mathrm{g} / \mathrm{kg}$ body-weight) was significantly lower in experimental animals in comparison with controls at $2,5,8,12$ and $20 \mathrm{~d}$ and significantly reduced below values at $0 \mathrm{~d}$ at $5,8,12$ and $20 \mathrm{~d}$.

4. Whole-body albumin mass was significantly reduced at 5, 8, 12 and $20 \mathrm{~d}$ when compared both with controls killed at the same time and animals killed at $\circ \mathrm{d}$. Measurement of the ratio, extravascular albumin mass : vascular albumin mass indicated a significant redistribution of whole-body albumin mass at 5 and $20 \mathrm{~d}$ and mean values for this ratio were always lower in experimental animals than in controls.

5. It was concluded that measurement of plasma albumin concentration does not indicate the true extent of whole-body albumin losses in protein deficiency since total vascular albumin mass is, to some extent, maintained at the expense of extravascular albumin mass.
\end{abstract}

Much attention has been focused on the significance of altered plasma protein concentrations in protein-energy malnutrition. Reductions in the concentration of albumin are recognized as being particularly important having both diagnostic value (Whitehead, Coward \& Lunn, I973; Hay, Whitehead \& Spicer, 1975) and clinical significance in relation to the development of oedema (Coward, 1975).

While plasma albumin concentration is functionally relevant, its measurement provides no information about the factors that determine it. Due consideration should be given to the alterations in plasma volume that may occur in malnutrition (Gómez, Ramos-Galván, Cravioto Moñóz \& Bienvenú, 1950; Cohen \& Hansen, I962; Alleyne, I966; Shakir, Hindawi \& El-Bedri, 1971) and the distribution of the whole-body albumin mass between the vascular and extravascular compartments.

Information already available on albumin distribution in malnourished children and experimental animals is incomplete. The conventional methods for measuring albumin distribution (reviewed by Schultze \& Heremans, I966) involve the use of models of albumin metabolism and their application to the metabolic fate of injected radioactive albumin. Some doubt has recently been cast on the adequacy of such models (Katz, Bonorris, Golden \& Sellers, I970), but with regard to making measurements during the development of malnutrition the over-riding problem is that 
associated with the absence of steady-state conditions, in respect of movements of albumin between body compartments and synthesis and catabolism, during the periods of time in which observations need to be made. For these reasons the usual approach adopted has been to estimate albumin distributions only after periods of malnutrition, when presumably steady states were reached; and in pigs (Payne \& Done, 1959), sheep (Fomichev, 1972), monkeys (Deo, Bhan \& Ramalingaswami, 1974) and man (Cohen \& Hansen, I962; Kudlička \& Kudličkova, I973) it was shown that albumin losses from the extravascular space were greater than those from the intravascular space. Attempts were made to measure albumin distributions in the non-steady state of the development of malnutrition in adult man (Hoffenberg, Black \& Brock, I 966), children (James \& Hay, I968) and rats (Freeman \& Gordon, 1964) but it was not possible to provide precise information. The indications were, however, that a substantial net movement of albumin from the extravascular to the vascular space was probably an early consequence of protein deprivation.

The present experiments were designed to provide more complete data on plasma volumes and the size of body albumin pools in protein-deficient rats. The experimental animals were fed on diets sufficiently low in protein to produce reductions in plasma albumin concentration but at the same time to allow some, albeit minimal, growth. This type of animal model has been regarded as being more realistic in terms of protein malnutrition in children than others in which the dietary deprivation is more severe (Lunn, Whitehead \& Baker, 1976).

To avoid the difficulties associated with the metabolic studies already described, the techniques used were based on those introduced by Katz et al. (1970) for the direct estimation of extravascular albumin mass and distribution. Serial observations were made to demonstrate the time course of any redistribution of albumin.

\section{EXPERIMENTAL}

\section{Animals and diets}

The rats were males of a black hooded strain from a colony maintained under specific-pathogen-free conditions at the laboratories. They were raised in groups of five in a litter and weaned when they were 3 weeks old on to the control diet containing $2 \mathrm{r}$ g protein $/ \mathrm{kg}$ described by Lunn et al. (I976). At 5 weeks of age they were allocated to control and experimental groups; rats in the former group continued to receive the control diet and the latter animals were given a low-protein diet containing $3^{\mathrm{I}} \mathrm{g}$ protein $/ \mathrm{kg}$ (Lunn et al. I976); diets were given ad lib. at all times. Ten rats were killed for analysis at the start of the experiment and a further seven to nine animals from control and experimental groups were killed at $2,5,8$, I2 and $20 \mathrm{~d}$ later.

\section{Analytical methods}

Techniques for the determination of plasma volume and vascular and extravascular albumin mass were essentially those described by Katz et al. (1970). After an overnight fast rats were anaesthetized by intraperitoneal injection of $60 \mathrm{mg}$ Nembutal $/ \mathrm{kg}$ bodyweight (Abbot Laboratories Ltd, Queensborough, Kent) and I $\mu \mathrm{Ci}$ human ${ }^{125 \mathrm{I}-}$ 


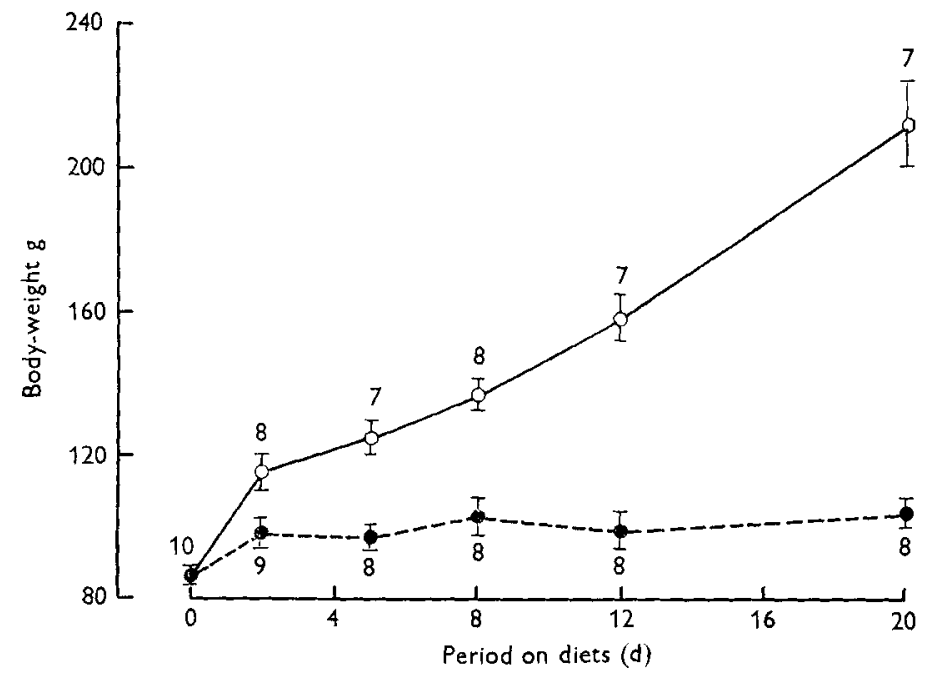

Fig. I. Body-weights of rats killed after periods of feeding on a control (2 ro $\mathrm{g}$ protein $/ \mathrm{kg}$ ) $(\mathrm{O}-\mathrm{O})$ or a low-protein $(3 \mathrm{I} \mathrm{g}$ protein $/ \mathrm{kg})(-\ldots)$ diet. Vertical bars represent standard errors of the means; values indicated are no. of animals/group.

labelled albumin (The Radiochemical Centre, Amersham, Bucks) in $20 \mu \mathrm{l}$ saline injected into the femoral vein using an Agla Micrometer syringe (Wellcome Reagents Ltd, Beckenham, Kent). About $3 \mathrm{ml}$ blood/ $100 \mathrm{~g}$ body-weight were collected 3-4 min later into a heparinized syringe by cardiac puncture. Plasma obtained from this sample was used in subsequent analysis. More blood was then removed and to deplete the tissues of residual blood still further, $5^{-10} \mathrm{ml}$ saline $(9 \mathrm{~g} \mathrm{NaCl} / 1)$ was injected into the heart and the fluid re-aspirated. The animals were then eviscerated, the entire skin and carcass minced and 10-20 $\mathrm{g}$ portions extracted as described by Katz et al. (1970) using a Silverson homogenizer with a slotted disintegrating head (Silverson Machines Ltd, Chesham, Surrey). Viscera were extracted directly without prior mincing.

The albumin content of the extracts and plasma samples were measured using quantitative immuno-electrophoresis (Laurell, 1966) with antiserum to rat albumin prepared in goats (Nordic Immunological Laboratories, Maidenhead, Berks). Plasma volumes were calculated from the estimated dilutions of injected radioactivity and corrections for trapped plasma albumin in the tissue extracts made using values derived for the specific activity of the plasma albumin and the radioactivity found in the tissue extracts.

\section{RESULTS}

Mean body-weights of the animals killed at each stage of the experiment are shown in Fig. I. The effects of the introduction of the low-protein diet were similar to those described by Lunn et al. (1976).

\section{Vascular albumin}

Changes in plasma albumin concentration, plasma volume and total vascular albumin mass during the experiment are shown in Fig. 2. Rats given the low-protein diet had plasma albumin concentrations that were lower than those found in control 

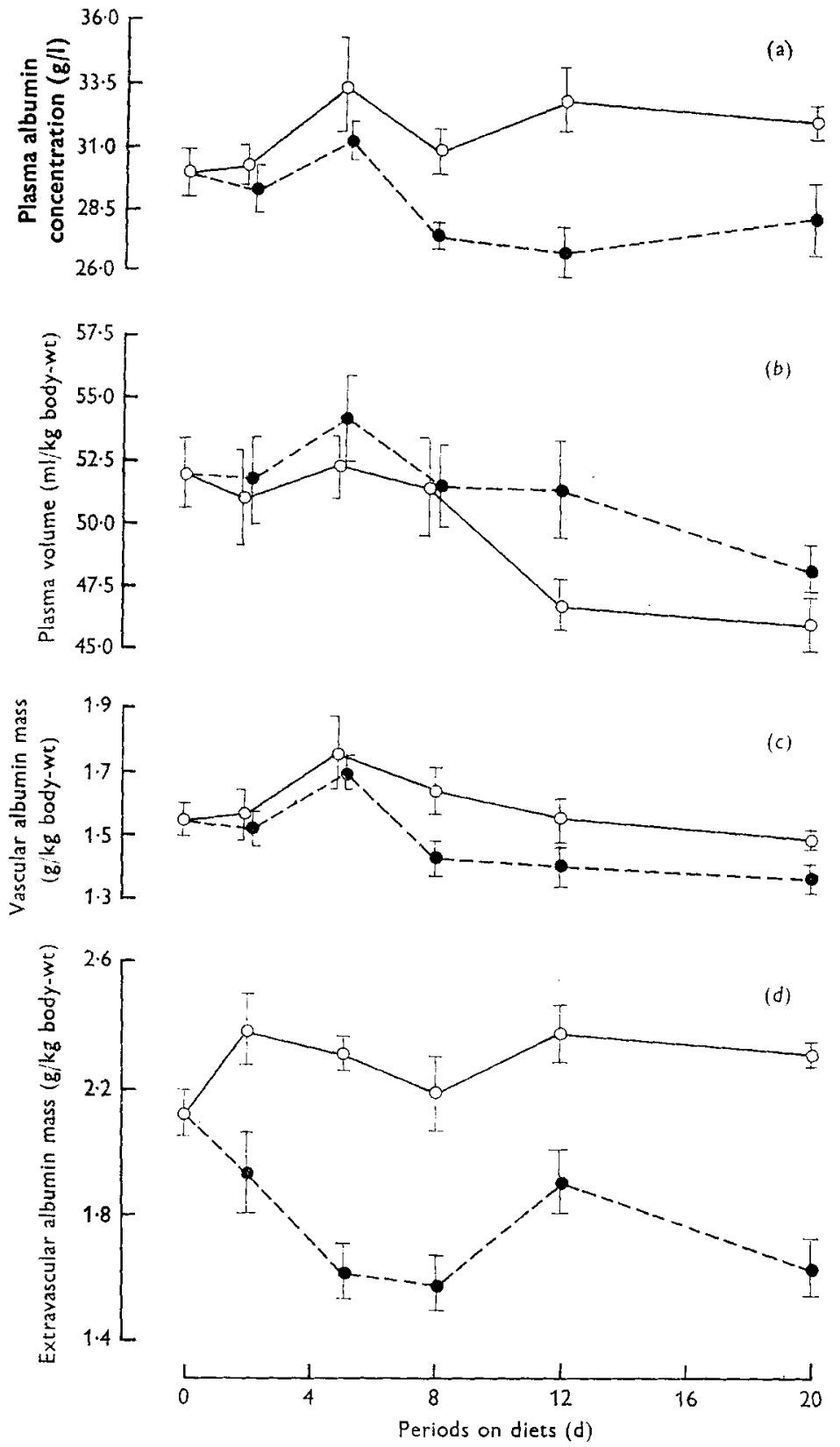

Fig. 2. (a) Plasma albumin concentration, $(b)$ plasma volume, (c) vascular albumin mass and (d) extravascular albumin mass in rats given the control (210 g protein $/ \mathrm{kg})(\bigcirc-\bigcirc)$ or low-protein ( $3 \mathrm{I} g$ protein $/ \mathrm{kg}$ ) ( - - - ) diet. Vertical bars represent standard errors of the means; nos. of animals/group were as shown in Fig. $r$. Significant differences between values for each dietary treatment were: for plasma albumin concentration, $20 \mathrm{~d} P<0.05,8$ and r 2 d $P<0.01$; for vascular albumin mass, 8 and $20 \mathrm{~d} P<0.05$; for extravascular albumin mass, 5, 8, I2 and $20 \mathrm{~d} P<0.00 \mathrm{r}$. Significant differences between values during the experiment in rats given the control diet and values at $\circ \mathrm{d}$ were: for plasma albumin concentration, $12 \mathrm{~d} P<0.05$; for plasma volume, $12 \mathrm{~d} P<0.05,20 \mathrm{~d} P<0.01$; for extravascular albumin mass, 2,12 and $20 \mathrm{~d} P<0.05$. Significant differences between values during the experiment in rats given the low-protein diet and values at o d were: for plasma volume, $20 \mathrm{~d} P<0.05$; for vascular albumin mass, $20 \mathrm{~d} P<0.05$; for extravascular albumin mass, $12 \mathrm{~d} P<0.05$; 5,8 and $20 \mathrm{~d} P<0.001$. Student's $t$-test was used in the analyses. 
animals and the differences were significant at 8,12 and $20 \mathrm{~d}$ after the start of the experiment. In contrast, plasma volumes $(\mathrm{ml} / \mathrm{kg}$ body-weight) tended to be greater in the rats given the low-protein diet although the differences were never significant. In both groups, plasma volumes decreased during the experimental period and were significantly reduced, compared to the starting values, at 12 and $20 \mathrm{~d}$ in control animals and at $20 \mathrm{~d}$ in the experimental group.

Total plasma albumin mass ( $\mathrm{g} / \mathrm{kg}$ body-weight) was always less in experimental animals compared to that in controls; the differences were significant at 8 and $20 \mathrm{~d}$. As with changes in plasma volume, control and experimental animals showed similar patterns of change during the experimental period and total plasma albumin mass was significantly reduced, when compared to that at the start of the experiment, at $20 \mathrm{~d}$ in animals given the low-protein diet.

\section{Extravascular albumin}

Reductions in the total albumin content of skin and carcass ( $\mathrm{g} / \mathrm{kg}$ body-weight) were marked and took place in the first few days of the experiment (Fig. 2); differences between control and experimental groups were significant each time measurements were made. Compared to starting values both groups of animals showed changes, extravascular albumin mass in control animals was significantly increased at 2,12 and $20 \mathrm{~d}$ but significantly decreased in experimental animals at 5, 8, 12 and $20 \mathrm{~d}$.

Results of the analyses of the viscera were very variable. In some analyses results comparable to those of Katz et al. (1970) were obtained and visceral albumin contributed about 10\% of the total body albumin mass, but in other animals from both control and experimental groups extremely low values were found. It seems likely that the problems associated with these analyses may have been caused by the breakdown of protein by digestive enzymes from the gut; Katz et al. (1970) briefly referred to this problem. Values for visceral albumin mass have not been included in the calculations of total body albumin mass or its distribution.

\section{Total body albumin mass and distribution}

Fig. 3 shows the serial alterations in total body albumin content ( $\mathrm{g} / \mathrm{kg}$ body-weight). Total body albumin mass was significantly reduced from $5 \mathrm{~d}$ onwards in experimental animals both when compared to control animals killed after the same period of time in the experiment and those killed at the start of the experiment. At $5 \mathrm{~d}$, control animals had a significantly larger total body albumin mass than at the start of the experiment.

Changes in the distribution of total body albumin between the vascular and extravascular compartments are indicated by the value of the ratio, total extravascular albumin mass: total vascular albumin mass. Serial alterations in this ratio are also shown in Fig. 3. In rats given the low-protein diet the value of the ratio was less than that in control animals at every stage in the experiment and differences were significant at 5 and $20 \mathrm{~d}$. At these times the ratio was also significantly less than that at the start of the experiment. 

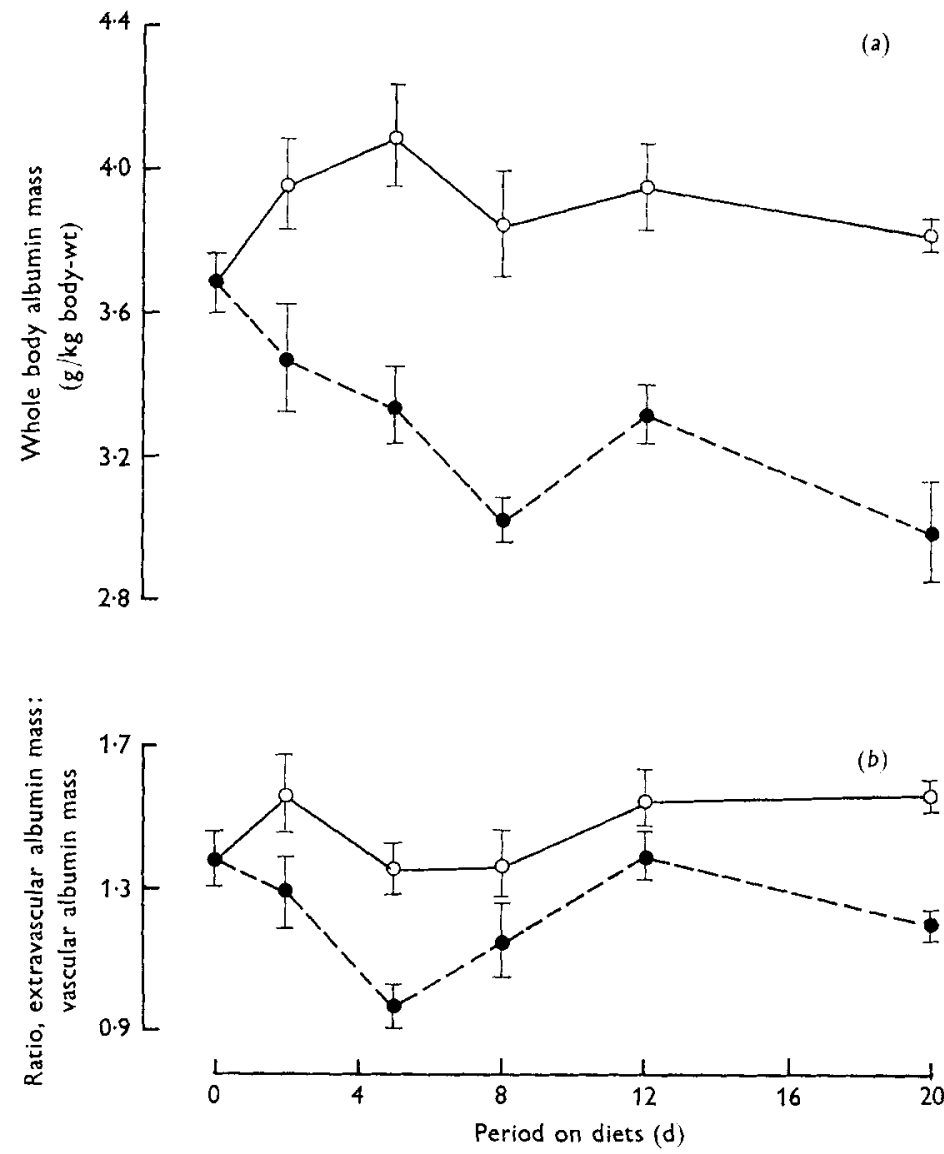

Fig. 3. (a) Whole-body albumin mass and (b) ratio, extravascular albumin mass:vascular albumin mass in rats given control (2 IO g protein $/ \mathrm{kg})(\mathrm{O}-\mathrm{O})$ or low-protein $(3 \mathrm{r}$ g protein $/ \mathrm{kg})$ (O- - ) diets. Vertical bars represent standard errors of the means; nos. of animals/group were as shown in Fig. I. Significant differences between values for each dietary treatment were: for whole-body albumin mass, 5, 8, 12 and $20 \mathrm{~d} P<0.00 \mathrm{r}$; for ratio, extravascular albumin mass : vascular albumin mass, $5 \mathrm{~d} P<0.01,20 \mathrm{~d} P<0.001$. Significant differences between values during the experiment in rats given the control diet and values at $\circ d$ were: for whole-body albumin mass, $5 \mathrm{~d} P<0.05$. Significant differences between values during the experiment in rats given the low-protein diet and values at o $\mathrm{d}$ were: for whole-body albumin mass, $5 \mathrm{~d} P<0.05$, 12 d $P<0.01,8$ and $20 \mathrm{~d} P<0.001$; for ratio, extravascular albumin mass : vascular albumin mass, $20 \mathrm{~d} P<0.05,5 \mathrm{~d} P<0.001$. Student's $t$-test was used in the analyses.

\section{DISCUSSION}

Plasma albumin concentrations in normal rats were similar to those reported by other workers and cited by Altman \& Dittmer (r961). Plasma volumes, expressed per unit body-weight, decreased as the animals grew older and gained weight; this observation confirms those of other workers for rats of similar age and weight (Metcoff \& Favour, I944; Lippman, I947; Wang \& Hegsted, I949; Belcher \& Harriss, I957; Garcia, 1957).

Values for circulating albumin mass given by Katz et al. (1970) averaged about $1 \cdot 3 \mathrm{~g} / \mathrm{kg}$. This value is somewhat lower than those found for normal rats in the 
present series of experiments. The reason for this disparity may be that these workers found lower plasma volumes in their rats; Sellers, Katz, Bonorris \& Okuyama (1966), for example, quote values of $35-40 \mathrm{ml} / \mathrm{kg}$.

Despite the fact that the same extraction procedures were used, and allowing for the small contribution of albumin from the viscera to total extravascular albumin mass, the amounts of extravascular albumin found in the present experiments were substantially lower than those reported by Katz et al. (1970) of $3 \cdot 64-5 \cdot 10 \mathrm{~g} / \mathrm{kg}$. This difference, combined with the likely difference in plasma volumes, explains the wide divergence of mean values for the ratio, extravascular:vascular albumin mass which were never less than 3.7 in the experiments of Katz et al. (1970) and not greater than $\mathrm{I} \cdot 6$ in the work reported here; Freeman \& Gordon (1964) found a ratio of $\mathrm{I} \cdot 8$ in normal hooded rats. In other experiments in this laboratory attempts have been made to increase the yields of extravascular albumin using other extraction procedures, but this has never been possible and it is difficult, therefore, to explain the differences between the present work and the only comparable published work without recourse to the assumption that values differ between strains of rats.

The results show that in rats given a low-protein diet measurements of plasma albumin concentration do not provide a true reflection of whole body albumin losses. Slight increases in plasma volume play some part in this but more importantly a greater proportion of total body albumin mass is lost from the extravascular space rather than from the plasma. These observations substantiate those of many other workers using different techniques and a wide variety of experimental subjects (Payne \& Done, 1959; Cohen \& Hansen, 1962; Freeman \& Gordon, 1964; Hoffenberg et al. 1966; James \& Hay, 1968; Fomichev 1972; Kudlička \& Kudličkova, I973; Deo et al. 1974), and the view that reductions in the extravascular albumin mass occur at an early stage in the development of protein malnutrition (Freeman \& Gordon, 1964; James \& Hay, I968) is also supported.

In protein malnutrition the alterations described are a consequence of lowered albumin synthetic rates but similar reductions in extravascular albumin mass also occur after plasmapheresis (Yuile, Lucas, Neubecker, Cochrane \& Whipple, 1959; Matthews, I96I) and haemorrhage (Wasserman, Joseph \& Mayerson, 1956) when presumably synthetic rates are normal or elevated, and consequently James \& Hay ( 1968 ) suggested that a fall in extravascular albumin mass is related to the depletion of the intravascular mass and not to the process by which this occurs; any explanation offered for the redistribution of whole body albumin mass in protein deficiency should take this point into account.

We thank Dr R. G. Whitehead for his interest and advice and Miss M. Howlett and Mr L. A. R. Luff for technical assistance.

\section{REFERENCES}

Alleyne, G. A. O. (1966). Archs Dis. Childh. 41, 313.

Altman, P. L. \& Dittmer, D. S. (1961). Blood and Other Body Fluids. Washington, DC: Federation of the American Society of Experimental Biologists.

Belcher, E. H. \& Harriss, E. B. (1957). F. Physiol., Lond. 139, 64. 
Cohen, S. \& Hansen, J. D. L. (1962). Clin. Sci. 23, 35 I.

Coward, W. A. (1975). Br. F. Nutr. 34, 459.

Deo, M. G., Bahn, A. K. \& Ramalingaswami, V. (1974). F. Nutr. 104, 858.

Fomichev, Y. P. (1972). Sel'khoz. biol. 7, $3^{8}$.

Freeman, T. \& Gordon, A. H. (1964). Clin. Sci. $26,17$.

Garcia, J. F. (1957). Am. J. Physiol. 190, 19.

Gómez, F., Rámos-Galván, R., Cravioto Moñóz, J. M. \& Bienvenú, B. (1950). Boln méd. Hosp. infant., Méx. 7, 5 I 4 .

Hay, R. W., Whitehead, R. G. \& Spicer, C. C. (1975). Lancet, ii, 427.

Hoffenberg, R., Black, E. \& Brock, J. F. (1966). F. clin. Invest. 45, $\times 43$.

James, W. P. T. \& Hay, A. M. (1968). F. clin. Invest. 47, 1958.

Katz, J., Bonorris, G., Golden, S. \& Sellers, A. L. (1970). Clin. Sci. 39, 705.

Kudlička, V. \& Kudličkova, V. (1973). Nutr. Rep. int. 8, I I I.

Laurell, C. B. (1966). Analyt. Biochem. 15, 45.

Lippman, R. W. (1947). Proc. Soc. exp. Biol. Med. 66, I88.

Lunn, P. G., Whitehead, R. G. \& Baker, B. A. (1976). Br. F. Nutr. 36, 219.

Matthews, C. M. E. (1961). J. clin. Invest. 40, 603.

Metcoff, J. \& Favour, C. B. (1944). Am. F. Physiol. 141, 695.

Payne, P. R. \& Done, J. (1959). Proc. Nutr. Soc. I8, vi.

Schultze, H. E. \& Heremans, J. F. (1966). Molecular Biology of Human Proteins, vol. I. Amsterdam, London and New York: Elsevier.

Sellers, A. L., Katz, J., Bonorris, G. \& Okuyama, S. (I966). F. Lab. clin. Med. 68, I77.

Shakir, A., Hindawi, A. Y. \& El-Bedri, A. L. (1971). Br. J. Nutr. 26, 227.

Wang, C. F. \& Hegsted, D. M. (1949). Am. F. Physiol. 156, 218.

Wasserman, K., Joseph, J. D. \& Mayerson, H. S. (1956). Am. Y. Physiol. 184, 175.

Whitehead, R. G., Coward, W. A. \& Lunn, P. G. (1973). Lancet i, 63.

Yuile, C. L., Lucas, F. V., Neubecker, R. D., Cochrane, C. G. \& Whipple, G. H. (1959). F. exp. Med. Iog, 165. 